\title{
LAMB WAVE-BASED MONITORING OF SHEAR FAILURE OF AN ADHESIVE LAP JOINT
}

\author{
Magdalena RUCKA, Erwin WOJTCZAK, Jacek LACHOWICZ
}

Gdańsk University of Technology, Faculty of Civil and Environmental Engineering, Department of Mechanics of Materials and Structures, Narutowicza 11/12, 80-233 Gdańsk, Poland e-mail: magdalena.rucka@pg.edu.pl, erwin.wojtczak@pg.edu.pl, jacek.lachowicz@pg.edu.pl

\begin{abstract}
The paper presents a study on the elastic wave propagation in adhesive joints of steel plates subjected to tensile loading. A single lap joint was chosen for analysis because of its simplicity and plurality of applications. Experimental investigations consisted of the uniaxial extension of prepared specimens. Force and displacement values were recorded by a testing machine. Simultaneously, guided Lamb waves were excited and signals of their propagation were collected in a number of points by piezoelectric transducers attached to the specimen surface. Further processing of signals allowed to determine some disturbances in gathered data. The continuous wavelet transform revealed discontinuities in force-displacement relations. The Fourier transform showed changes in frequency values of recorded signals. Large disturbances of the root mean square values were also observed. The results of all analyses allowed to conclude that the identification of partial degradation state before the sample destruction was possible.
\end{abstract}

Keywords: adhesive joint, tensile loading, ultrasonic waves, damage assessment, structural health monitoring

\section{MONITOROWANIE ZNISZCZENIA ŚCINANEGO POŁĄCZENIA KLEJONEGO ZA POMOCĄ FAL LAMBA}

\section{Streszczenie}

Artykuł przedstawia badania propagacji fal sprężystych w połączeniach klejonych płyt stalowych poddanych działaniu obciążenia rozciągającego. Pojedyncze złącze zakładkowe zostało wybrane do analizy ze względu na jego prostotę i mnogość zastosowań. Badania eksperymentalne polegały na jednoosiowym rozciąganiu przygotowanych próbek. Wartości siły i przemieszczenia były zapisywane przez maszynę wytrzymałościową. Jednocześnie, wzbudzano fale prowadzone Lamba, a sygnały ich propagacji rejestrowano w kilku punktach za pomocą czujników piezoelektrycznych przymocowanych do powierzchni próbki. Dalsza obróbka sygnałów pozwoliła na wykrycie pewnych zaburzeń w zebranych danych. Ciągła transformacja falkowa ukazała nieciągłości w zależnościach siła-przemieszczenie. Transformacja Fouriera pokazała zmiany w wartościach częstotliwości zarejestrowanych sygnałów. Zaobserwowano także duże skoki wartości średniej kwadratowej. Wyniki przeprowadzonych analiz pozwoliły na sformułowanie wniosku, iż identyfikacja stanu częściowej degradacji przed zniszczeniem próbek była możliwa.

Słowa kluczowe: złącze klejone, obciążenie rozciągające, fale ultradźwiękowe, ocena uszkodzeń, monitoring techniczny

\section{INTRODUCTION}

Structural adhesive joints are a specific kind of non-separable connections that can be applied in many fields of engineering. They have numerous applications in metal structures for automotive, aviation, machine and architecture industry $[2,11]$. One of the simplest types of the adhesive connections is a single-lap joint that consists of two adherends (i.e. joined members) and a glue layer attached to both of them at a certain area named an overlap. The connection is in general subjected to shearing triggered by the extension or compression of adherends. The failure of the adhesive joint may occur in the form of one of two fundamental types of mechanisms. There can be the cohesive mechanism that is the desirable one and it consists in the destruction of the internal structure of the adhesive layer (the glue remains on the whole surface of both adherend overlaps). Another mechanism is called the adhesive failure and it performs when the connection between the glue and adherend is poor but the adhesive layer is not destroyed itself. The glue may remain completely at one adherend or partially at both of them but not at the same place of the overlap. In practice, there can also exist a third variant called the mixed failure mechanism that has features of both fundamental ones (delamination occurs partially in the adhesive layer and between the adhesive and the adherends).

It is well-known that the failure of adhesive joints is not allowed in real engineering structures. For that reason, many significant issues need to be considered during the process of designing and 
preparation of adhesive joints. The strength of a connection is mainly determined by the overlap size, the condition of surfaces of adherends at the area of the overlap, the adhesive layer thickness and the mechanical properties of the applied adhesive material. These parameters may partially change in a process of exploitation of the joint, especially if the adherends are subjected to large loads or temperature. The essential problem is that the direct measurement of discussed parameters is usually not possible for the elements of existing structures without violating their integrity. This issue leads to the need for searching for non-destructive techniques that may signalize an emergency state of the joint before it collapses, e.g. ultrasonic, vibroacoustic, radiographic, or thermographic methods. Recently, a dynamic development of wave propagation-based techniques for a quality assessment of existing structures has been observed (e.g. $[1,3,5,16])$. Ultrasonic waves can also be utilized for monitoring of structural elements subjected to mechanical degradation. Such approach was successfully used in many studies, for example, monitoring of damage progress in bolted joints [18], failure monitoring of steel-concrete connections [13] or damage evaluation of bending concrete beams [10, 15]. Adhesive joints under certain fatigue or tensile loads are also an object of the research, e.g. $[6,17,20]$.

To provide clearly interpretable information, the registered ultrasonic signals usually require further processing. There are many methods that may be utilized for the effective analysis of data collected during measurements. The Fourier transform (FT) is the operation that converts signals from the time domain to the frequency domain. It enables the identification of dominant frequency components of recorded signals. The Fourier transform can be used as the basis for advanced methods of damage detection, e.g. the Fourier spectral-based method applied successfully for beams [19]. Another efficient instrument is the calculation of the root mean square (RMS). The method is based on the vibration energy distribution and it was efficiently applied for damage detection of various defects. Some of the examples are: damaged rivets in platelike structures [12], delamination in a composite web-flange joint [4] or notches of different geometry in plates [7]. The continuous wavelet transform (CWT) is a useful technique for the identification of signal discontinuities [9]. It was successfully applied for identification of defects in various type of structures, such as debonding in CFRP-reinforced concrete beams [8] or cracks in beam, plate and cylindrical structures [14].

This paper is devoted to structural health monitoring (SHM) of shear failure of an adhesive joint. Experimental investigations were performed on four steel lap joints subjected to simultaneous tensile loading and propagation of Lamb waves. The main aim of the study was the examination of
Lamb waves to predict upcoming damage before the joint shear failure occurred.

\section{MATERIALS AND METHODS}

\subsection{Geometry of samples}

The experimental investigations were carried out for a single lap adhesive joint of steel plates. The dimensions of each steel plate were $270 \mathrm{~mm} \times 120 \mathrm{~mm} \times 3 \mathrm{~mm}$. The plates were joined with the use of epoxy-based glue Loctite EA 9461 at the length of the overlap equal to $60 \mathrm{~mm}$. Before applying the adhesive layer both steel elements were degreased with Loctite-7063 cleaner and dried. The area of the connection was also treated with the abrasive paper (type P120). In addition, to ensure the axial work of the connection in the testing machine, additional steel elements with dimensions of $120 \mathrm{~mm} \times 50 \mathrm{~mm}$ were adhesively bonded to the place where the joint was fixed in the jaws of the testing machine. The geometry of the analyzed joint is shown in Figure 1.

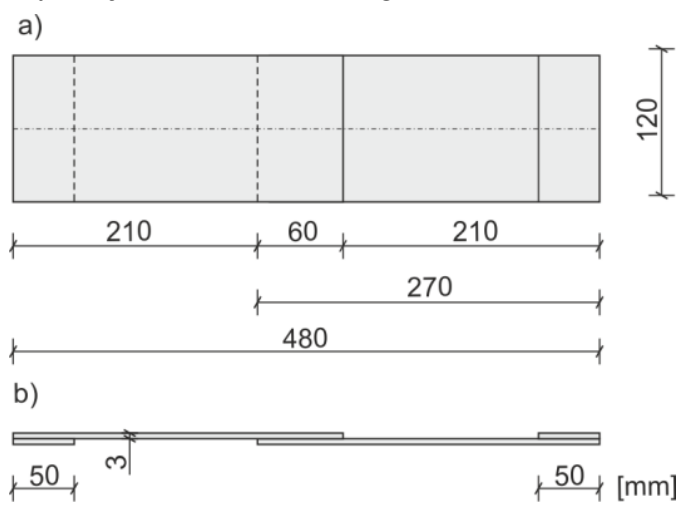

Fig. 1. Geometry of the adhesive joint (a) plane view; (b) side view

\subsection{Test set-up}

The experimental measurements consisted in uniaxial extension of the adhesive joint and simultaneous excitation of the Lamb waves at one of the steel plates. The experimental setup is presented in Figure 2. The Z100 (Zwick Roell) testing machine was used for the uniaxial extension test. After placing the test sample in the machine jaws, an initial force of $100 \mathrm{~N}$ was applied and then the test was continued at a speed of $2 \mathrm{~mm} / \mathrm{min}$ until the joint rupture.

During the uniaxial extension test, Lamb waves were excited and recorded every $1 \mathrm{~s}$. The ultrasonic system consisted of the arbitrary function generator AFG 3022 (Tektronix), the high-voltage amplifier P200 (FLC Electronics) and the digital oscilloscope PicoScope 4824 (Pico Technology). For the excitation and signal registration, a set of the piezoelectric transducers NAC2024 (Noliac) attached to the steel elements using the petro wax was used. The location of the measurement points is shown in Figure 3. The excitation signal was a 50-cycle wave packet obtained from a sinusoidal function with a $100 \mathrm{kHz}$ carrier frequency 
modulated by the Hanning window. The sampling frequency was $10 \mathrm{MHz}$ and the length of each registered signal was $2 \mathrm{~ms}$.

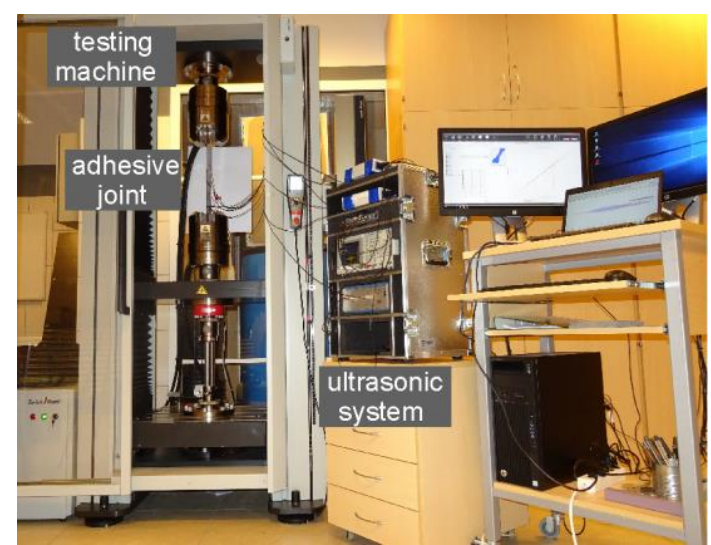

Fig. 2. Experimental setup

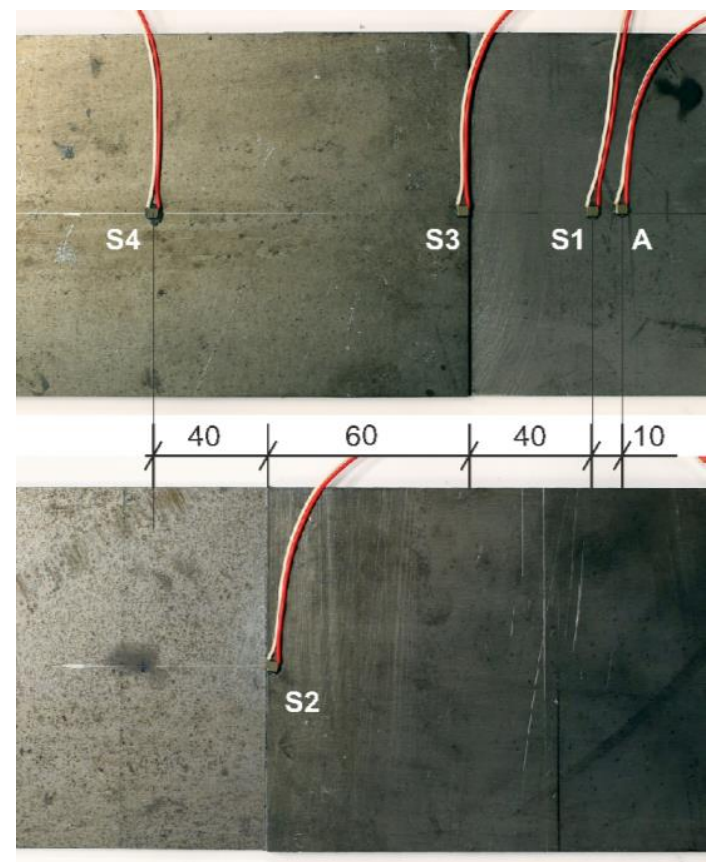

Fig. 3. Steel adhesive lap joint with attached piezoelectric transducers for Lamb wave measurements (A - actuator, S1-S4 - sensors)

\subsection{Data processing}

In this study, the experimental data were processed using the Fourier transform, the continuous wavelet transform and the root mean square. The Fourier transform provides the frequency representation of a time signal $x(t)$ according to the formula [9]:

$$
X(\omega)=\left\langle x, e^{-i \omega t}\right\rangle=\int_{-\infty}^{\infty} x(t) e^{-i \omega t} d t
$$

where $X(\omega)$ denotes the Fourier coefficients and $\omega$ is the circular frequency. The values of the Fourier coefficients $X(\omega)$ are received by the time integration of the product of the signal $x(t)$ and the complex exponential component $e^{-i \omega t}$ for a specific circular frequency $\omega$. The product has a large amplitude if the signal $x(t)$ contains the component related to the frequency $\omega$.

Another way to represent a signal brings the wavelet transform. For a given time signal $x(t)$, the continuous wavelet transform can be defined as the inner product of the signal function with the family of wavelet functions $\psi_{u, s}(t)[9,14]$ :

$$
W(u, s)=\left\langle x, \psi_{u, s}\right\rangle=\int_{-\infty}^{\infty} x(t) \frac{1}{\sqrt{s}} \psi^{*}\left(\frac{t-u}{s}\right) d t
$$

where the real numbers $s$ and $u$ denote the scale and translation parameters, respectively. The family of wavelets is created from the so-called mother wavelet $\psi(t)$, which is translated and scaled:

$$
\psi_{u, s}(t)=\frac{1}{s} \psi\left(\frac{t-u}{s}\right)
$$

As a result, the wavelet coefficients $W(u, s)$ provide the time-scale representation of a signal. A very important feature of the continuous wavelet transform is the ability of detection of any local discontinuities contained in a signal. The effectiveness of their localization is strongly connected with the idea of vanishing moments. A wavelet has $n$ vanishing moments if it is orthogonal to the polynomial of order $(n-1)$ (cf. [9, 14]):

$$
\int_{-\infty}^{+\infty} x^{n} \psi(t) d t=0, \quad n=0,1,2, \ldots, k-1
$$

In this study, the Gaussian wavelet (Fig. 4) with two vanishing moments was used

$$
\psi(t)=(-1)^{2} \frac{2 \sqrt[4]{2 / \pi}}{\sqrt{3}}\left(1-2 t^{2}\right) e^{-t^{2}}
$$

to analyze the load-displacement curve, which resembles the first degree polynomial. In this way, the non-zero wavelet coefficients will only occur at the discontinuities of the signal.

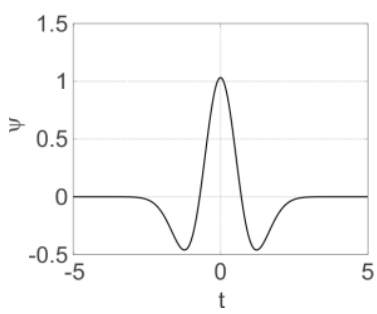

Fig. 4. Gaussian wavelet with two vanishing moments

The root mean square for a signal $x(t)$ represented in the time domain can be defined as follows (e.g. [12]):

$$
R M S=\sqrt{\frac{1}{t_{2}-t_{1}} \int_{t_{1}}^{t_{2}} x(t)^{2} d t} .
$$

In the formula, $\left(t_{2}-t_{1}\right)$ denotes the length of a time window with $t_{1}$ and $t_{2}$ indicating the beginning and the end of the window, respectively. 


\section{RESULTS AND DISCUSSION}

The experimental measurements were carried out on four samples with the same geometry (denoted as \#1, \#2, \#3, and \#4). The adhesive layer was applied to the samples by hand, making impossible to keep the exact adhesive layer thickness. The average thickness of the adhesive layer for particular specimens was: $0.22 \mathrm{~mm}$, $0.28 \mathrm{~mm}, 0.3 \mathrm{~mm}$ and $0.27 \mathrm{~mm}$, respectively.

Figure 5 presents the experimental forcedisplacement curves. It can be seen that significant discrepancies in the maximum force occurred for particular joints. Figure 6 shows the photographs of the adhesive joints after shear failure. Various patterns of failure can be observed. The failure generally had an adhesive mechanism for all specimens but each adhesive layer was different (glue was attached in different proportions to each adherend).
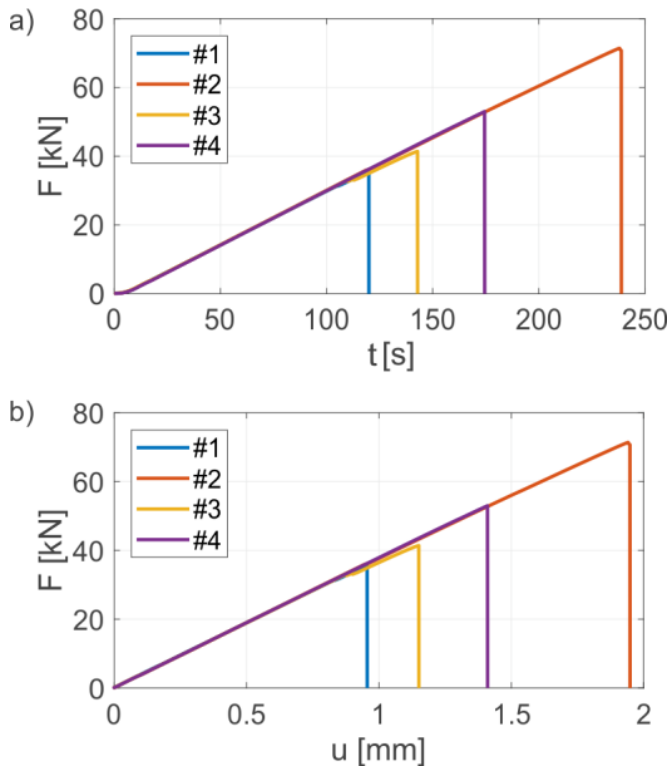

Fig. 5. Results of tensile test: a) force-time curve, b) force-displacement curve

The signals recorded by sensors S2, S3, S4 were subjected to the data processing algorithms described in Section 2.3 (sensor S1 was used to trigger the signals). Algorithms have been selected to observe the condition of the adhesive bond before the separation of plates.

The first way to analyze these data was the Fourier transform. As already mentioned, the signals were excited and registered every $1 \mathrm{~s}$ during the uniaxial extension test. For each signal, the FT was performed to observe the main frequency components. Figure 7 shows the Fourier transforms for all signals registered during the entire tensile test. The presented maps reveal how the main signal frequency changed during the degradation process. For each tested joint, it was observed that the carrier frequency did not change at the initial stage of the test, remaining near the excited frequency of the input packet, i.e. $100 \mathrm{kHz}$. Then, before the bonding failure, the main frequency fluctuated considerably and the shift of the frequency can be observed indicating nonlinear Lamb wave propagation in the joint.
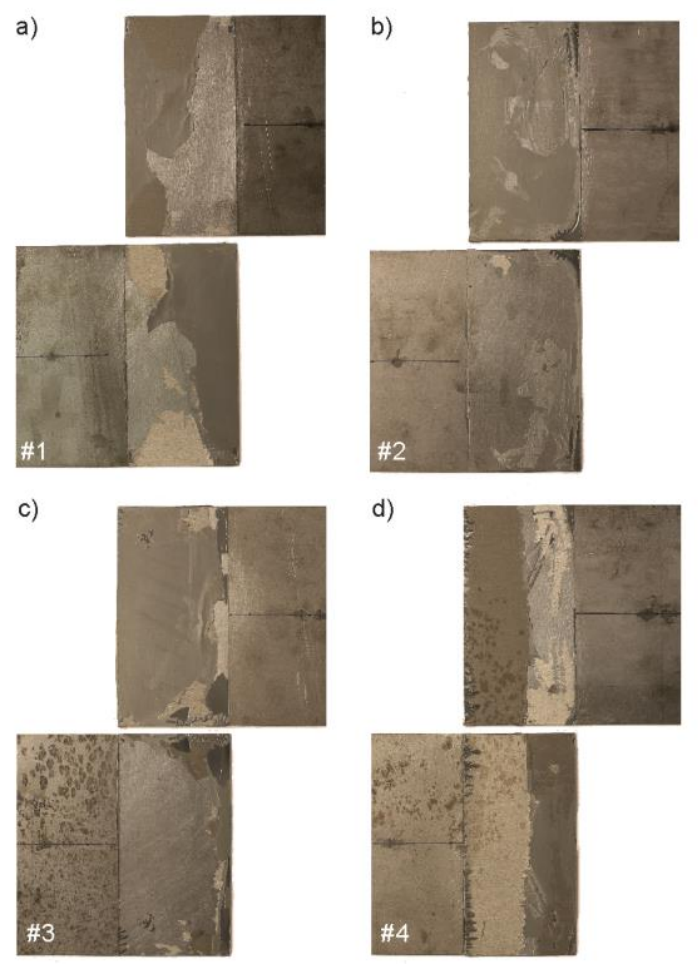

Fig. 6. Photographs of investigated joints after failure: a) joint \#1, b) joint \#2, c) joint \#3, d) joint \#4

Figure 8 shows the comparison of the wavelet transforms of the force-time relations and the RMS values of the guided wave signals. The charts are presented in regard to the time duration of the mechanical degradation defined individually for each sample by the duration of the tensile test. As we can see in Figure 8a, the force values changed quasi-linearly and in the case of joints \#1, \#2 and \#4 no break-down points are visible in the forcetime curves. Only for joint \#2, a small disturbance can be observed at $t=110 \mathrm{~s}$. Figure $8 \mathrm{~b}$ shows the CWT results in the form of two-dimensional maps of the wavelet transform modulus that vary in regard to time of degradation $t$ and scale $s$. To clarify the results, the variability of the modulus of the wavelet coefficient $W$ is presented for a specific scale value $s=20$. The values of the CWT modulus are near zero except few peaks indicating the location of the signal singularities. The first repeatable conclusion for each joint is that there is a disturbance for $t$ of approximately $20 \mathrm{~s}$. This effect may result from the slip of the specimen in the machine jaws. Further peaks are individual for each specimen because of different joint strengths and failure patterns.

Turning to Figure $8 \mathrm{c}$, the RMS values in relation to the degradation time are approximately constant or smoothly monotonic at the beginning of the tensile test for all samples. This proves that the 
first peak observed in the CWT modulus is related to the slip of the specimen rather than its structural destruction. With the increase of time (and, in fact, the force value) some sharp disturbances appeared. It is clearly visible that these disturbances are related to the peaks existing in CWT charts (Figure 8b). For example, for specimen \#2 the RMS value of signal $\mathrm{S} 2$ increases significantly at a time of about $120 \mathrm{~s}$ whereas RMS values for S3 and S4 have clear local disorders at the same time. Similar conclusions can be obtained from the analysis of remaining graphs, because each sharp disturbance in the RMS chart have a reflection in a corresponding wavelet transform. What is more, comparing Figures 7 and 8, there are some relations between Fourier transforms and wavelet transforms. For each specimen, no significant disturbance is observed in FFT until the peak appears in the CWT. a)

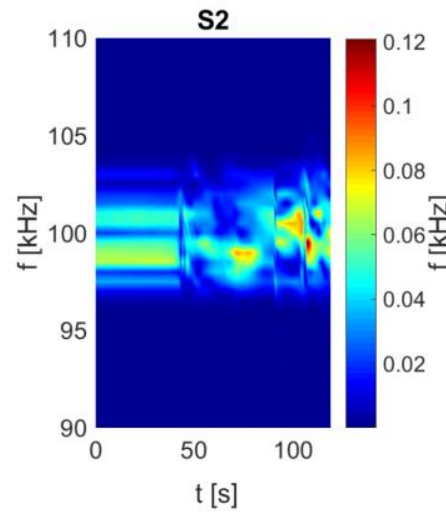

b)

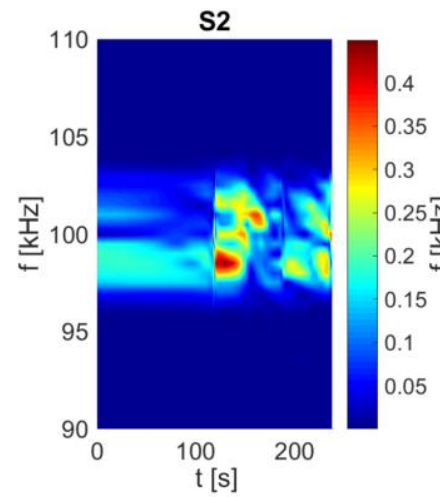

c)

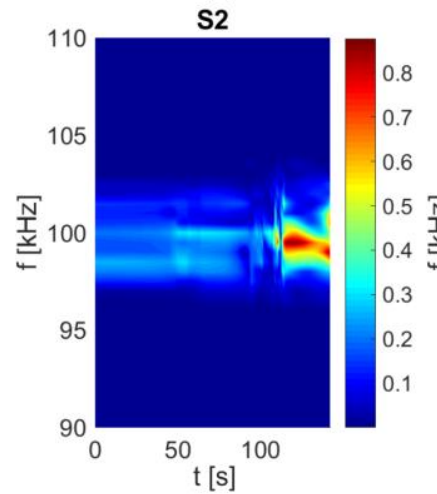

d)

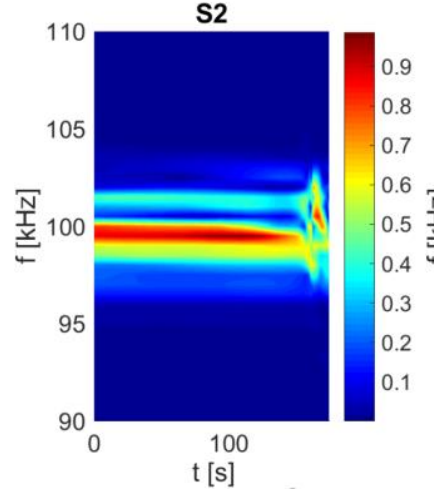

S3

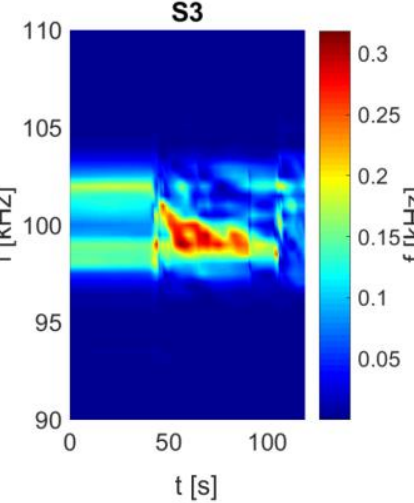

S3

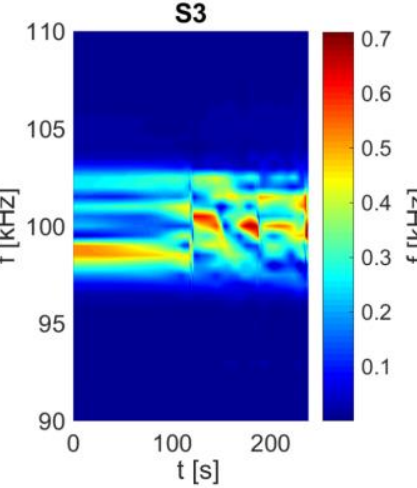

s3

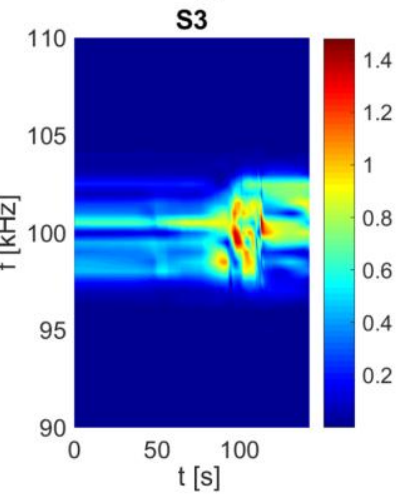

s3

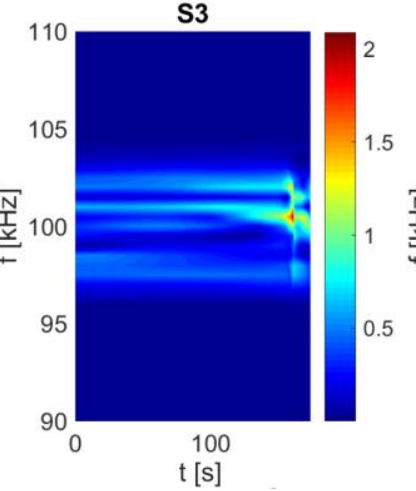

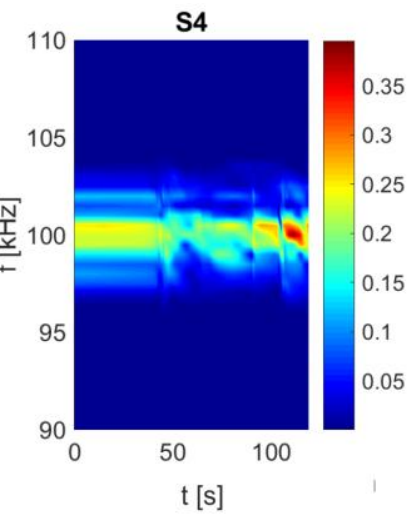

S4

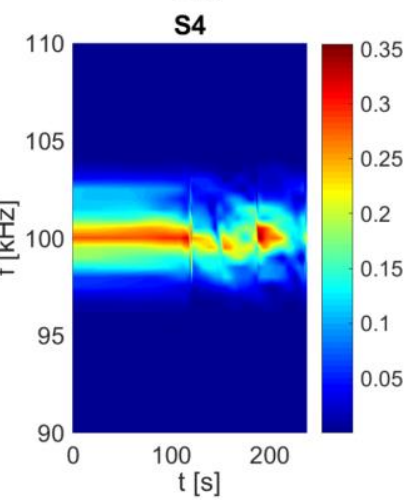

s4
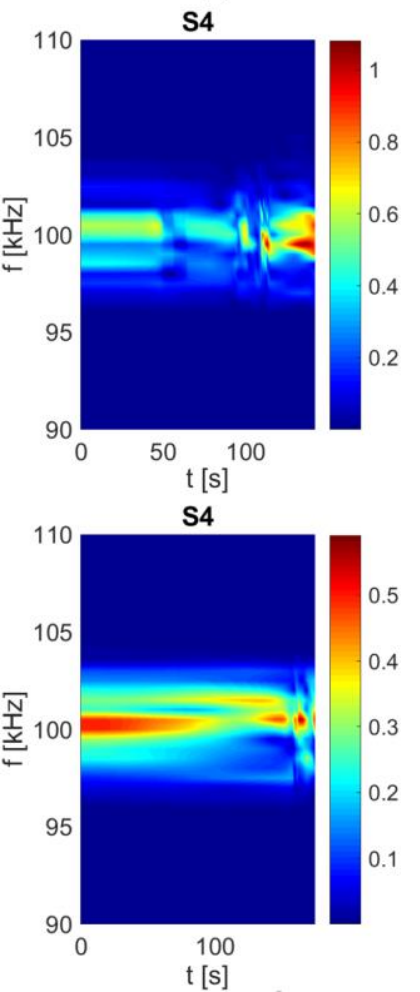

Fig. 7. FT results for signals registered by sensors S2, S3, S4: a) joint \#1, b) joint \#2, c) joint \#3, d) joint \#4 

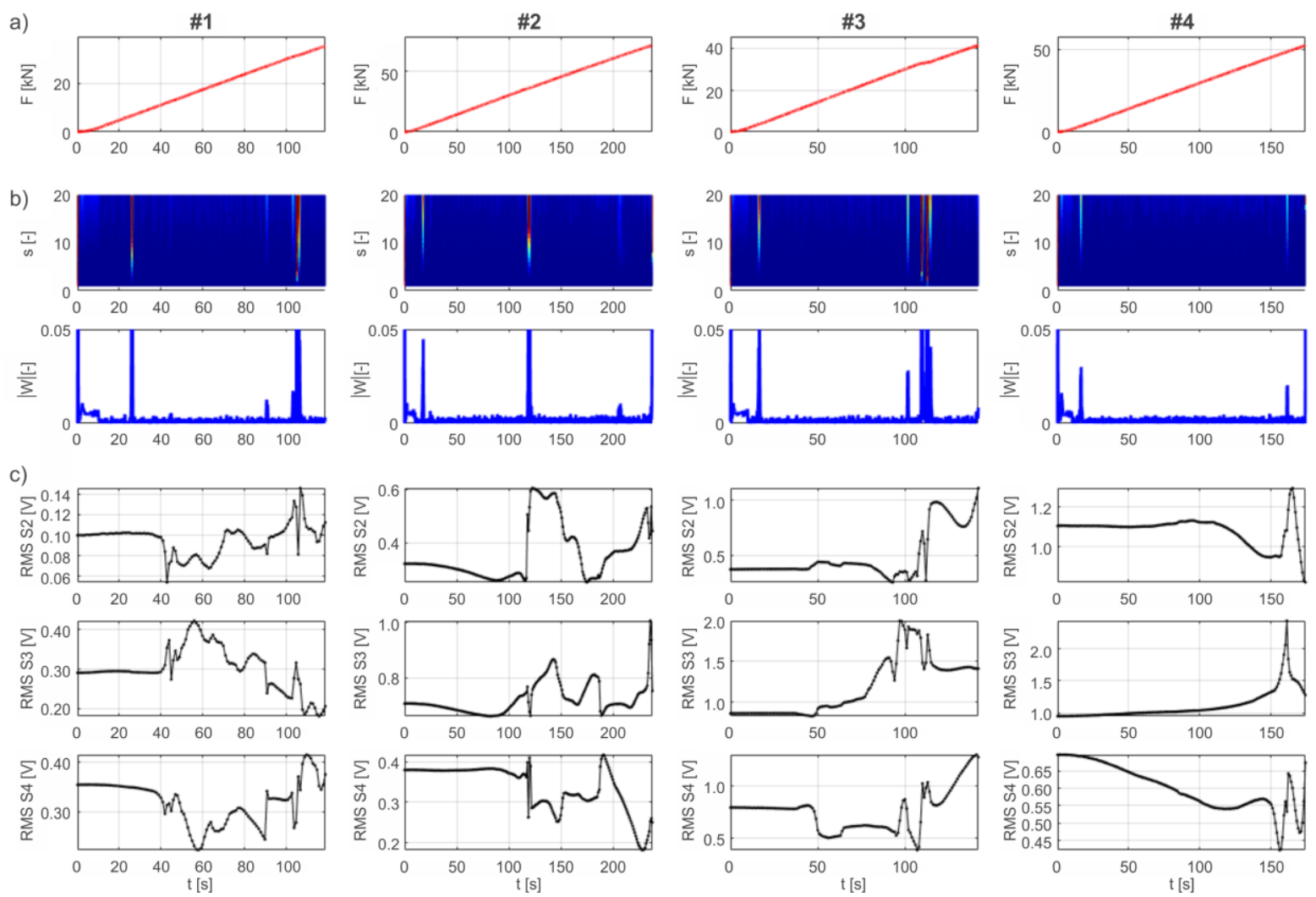

Fig. 8. Comparison of CWT and RMS results for joints \#1-\#4 (in regard to time of mechanical degradation): a) force values, b) wavelet transforms of force-time relations (maps of wavelet coefficients $W$ in scale-time coordinates and values of $W$ for $s=20$ ), c) RMS values for ultrasonic signals S2, S3 and S4

\section{CONCLUSIONS}

The paper presents the research on the guided Lamb wave propagation in the single lap adhesive joint under tensile load. The results of experimental measurements were subjected to processing techniques such as the Fourier transform, the continuous wavelet transform and the root mean square calculation. All methods allowed to identify certain discontinuities in the recorded data for each tested specimen.

The frequency analysis of signals made by the FT indicated some changes in the main frequencies of the recorded signal; especially frequency shifts were observed prior to the emergency state. The CWT revealed disturbances in the force-time relations connected with both the mechanical damage of the joint and the slip of the joint in the testing machine. The RMS values showed discontinuities at the same instants when the mechanical damage occurred. The strong relation between the CWT analysis of the load-time relations and the examination of ultrasonic signals with the RMS and the FT resulted in the conclusion that emergency state can be identified before the sample shear failure.

\section{ACKNOWLEDGEMENTS}

The authors would like to acknowledge the National Science Centre, Poland for the support for this research within project No. 2015/19/B/ST8/00779.

\section{REFERENCES}

1. Adams RD, Drinkwater BW. Nondestructive testing of adhesively-bonded joints. NDT\&E International 1997; 30: 93-98. https://doi.org/10.1016/S0963-8695(96)00050-3

2. Adams RD, Wake WC. Structural adhesive joints in engineering. 1st ed. London and New York: Elsevier Applied Science Publishers; 1984. https://doi.org/10.1007/978-94-009-5616-2

3. Garbacz A. Application of stress based NDT methods for concrete repair bond quality control. Bulletin of the Polish Academy of Sciences: Technical Sciences. 2015; 63:77-85. https://doi.org/10.1515/bpasts-2015-0009

4. Geetha GK, Roy Mahapatra D, Gopalakrishnan S, Hanagud S. Laser Doppler imaging of delamination in a composite $\mathrm{T}$-joint with remotely located ultrasonic actuators. Composite Structures 2016; 147: 197-210.

https://doi.org/10.1016/j.compstruct.2016.03.039

5. Giurgiutiu V. Structural Health Monitoring: with Piezoelectric Wafer Active Sensors. 1st ed. Amsterdam: Elsevier; 2008.

6. Khashaba UA, Najjar IMR. Adhesive layer analysis for scarf bonded joint in CFRE composites modified with MWCNTs under tensile and fatigue loads. Composite Structures 2018; 184: 411-427. https://doi.org/10.1016/j.compstruct.2017.09.095

7. Lee C, Park S. Flaw imaging technique for plate-like structures using scanning laser source actuation. 
Shock and Vibration 2014; 725030.

http://dx.doi.org/10.1155/2014/725030

8. Li J, Lu Y., Guan R, Qu W. Guided waves for debonding identification in CFRP-reinforced concrete beams. Construction and Building Materials 2017; 131: 388-399. https://doi.org/10.1016/j.conbuildmat.2016.11.058

9. Mallat S. A Wavelet Tour of Signal Processing: The Sparse Way. 3rd ed. Orlando: Academic Press; 2009.

10. Moradi-Marani F, Rivard P, Lamarche CP, Kodjo SA. Evaluating the damage in reinforced concrete slabs under bending test with the energy of ultrasonic waves. Construction and Building Materials 2014; 73: 663-673.

https://doi.org/10.1016/j.conbuildmat.2014.09.050

11. Piekarczyk M, Grec R. Application of adhesive bonding in steel and aluminium structures. Archives of Civil Engineering 2012; LVIII (3): 309-329. https://doi.org/10.2478/v.10169-012-0018-8

12. Radzieński M, Doliński Ł, Krawczuk M, Palacz M. Damage localisation in a stiffened plate structure using a propagating wave. Mechanical Systems and Signal Processing 2013; 39: 388-395.

https://doi.org/10.1016/j.ymssp.2013.02.014

13. Rucka M. Failure Monitoring and Condition Assessment of Steel-Concrete Adhesive Connection Using Ultrasonic Waves. Applied Sciences 2018; 8(3): 320. https://doi.org/10.3390/app8030320

14. Rucka M, Wilde K. Application of wavelet analysis in damage detection and localization. 1 ed. Gdańsk: Wydawnictwo Politechniki Gdańskiej; 2007.

15. Rucka M, Wilde K. Ultrasound monitoring for evaluation of damage in reinforced concrete. Bulletin of the Polish Academy of Sciences Technical Sciences 2015; 63: 65-75.

https://doi.org/10.1515/bpasts-2015-0008

16. Schabowicz K. Ultrasonic tomography - The latest nondestructive technique for testing concrete members - Description, test methodology, application example. Archives of Civil and Mechanical Engineering 2014; 14: 295-303. https://doi.org/10.1016/j.acme.2013.10.006

17. Shui G, Wang Y, Huang P, Qu J. Nonlinear ultrasonic evaluation of the fatigue damage of adhesive joints. NDT\&E International 2015; 70: 9-15. https://doi.org/10.1016/j.ndteint.2014.11.002

18. Yang B, Xuan F, Xiang Y, et al. Lamb Wave-Based Structural Health Monitoring on Composite Bolted Joints under Tensile Load. Materials 2017; 10(6): 652. https://doi.org/10.3390/ma10060652

19. Yang Z, Radzieński M, Kudela P, Ostachowicz W. Fourier spectral-based modal curvature analysis and its application to damage detection in beams. Mechanical Systems and Signal Processing 2017; 84:763-781. https://doi.org/10.1016/i.ymssp.2016.07.005

20. Ye J, Yan Y, Li J, Hong Y, Tian Z. 3D explicit finite element analysis of tensile failure behavior in adhesive-bonded composite single-lap joints. Composite Structures 2018; 201: 261-275. https://doi.org/10.1016/j.compstruct.2018.05.134

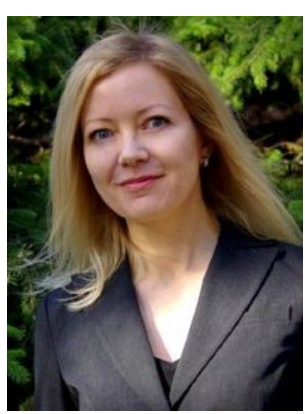

Magdalena RUCKA, Ph.D., D.Sc. is an associate professor at the Department of Mechanics of Materials and Structures, Gdansk University of Technology. Her scientific interests are focused on the dynamics of structures, wave propagation and development of new techniques for damage detection and structural health monitoring.

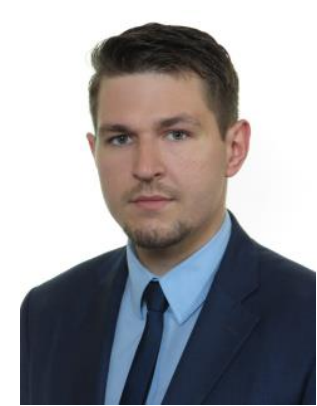

Erwin WOJTCZAK, M.Sc. is an assistant at the Department of Mechanics of Materials and Structures, Gdansk University of Technology. He graduated civil engineering at the Faculty of Civil and Environmental Engineering. Since October 2017 he continues education as a Ph.D. student. He mainly deals with non-destructive diagnostics of adhesive joints.

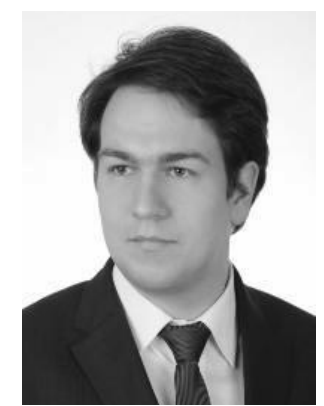

Jacek LACHOWICZ, Ph.D. graduated civil engineering at the Department of Mechanics of Materials and Structures of Gdańsk University of Technology. He mainly deals with NDT methods. 